\title{
Bacteria and methanogen community in the rumen fed different levels of grass-legume silages
}

\author{
RONI RIDWAN ${ }^{1, \bullet}$, IMAN RUSMANA ${ }^{2}$, YANTYATI WIDYASTUTI ${ }^{1}$, KOMANG G. WIRYAWAN ${ }^{3}$, \\ BAMBANG PRASETYA ${ }^{1}$, MITSUO SAKAMOTO ${ }^{4}$, MORIYA OHKUMA ${ }^{4}$ \\ ${ }^{1}$ Research Center for Biotechnology, Indonesian Institute of Sciences. J1. Raya Jakarta Bogor Km. 46, Cibinong, Bogor 16911, West Java, Indonesia \\ Tel:+62-21-8754587, Fax: +62-21-8754588, `email: roni001@lipi.go.id, rony_biotech@yahoo.com \\ ${ }^{2}$ Department of Biology, Faculty of Mathematics and Natural Sciences, Institut Pertanian Bogor. Jl. Raya Dramaga, Bogor 16680, West Java, Indonesia \\ ${ }^{3}$ Department of Animal Nutrition, Faculty of Animal Sciences, Institut Pertanian Bogor. Jl. Raya Dramaga, Bogor 16680, West Java, Indonesia \\ ${ }^{4}$ Microbe Division/Japan Collection of Microorganisms RIKEN Bioresource Center, Tsukuba, Ibaraki, Japan
}

Manuscript received: 7 January 2019. Revision accepted: 22 March 2019.

\begin{abstract}
Ridwan R, Rusmana I, Widyastuti Y, Wiryawan KG, Prasetya B, Sakamoto M, Ohkuma M. 2019. Bacteria and methanogen community in the rumen fed different levels of grass-legume silages. Biodiversitas 20: 1055-1062. This study aimed to investigate the effects of dietary grass-legume silages on the microbial community by using a culture-independent approach. Treatments consisted of R0: 50\% Pennisetum purpureum and $50 \%$ concentrate; R1: $20 \%$ P. purpureum, $50 \%$ concentrate, and $30 \%$ grass-legumes silage; R2: $20 \%$ P. purpureum, $35 \%$ concentrate, and $45 \%$ grass-legumes silage; and R3; $20 \%$ P. purpureum, $20 \%$ concentrate, and $60 \%$ grasslegumes silage. The rumen fluid obtained from fistulated cattle was used for T-RFLP, 16S rDNA clone library, and qPCR analyses. The results indicated that bacterial diversity was dominated by Bacteroidetes, Firmicutes, and methanogen by Methanobacteriales, based on partial 16S rDNA sequences. The microbial communities were dominated by Prevotella brevis, P. ruminicola, Succiniclasticum ruminis, and Methanobrevibacter ruminantium, M. smithi, M. thueri, and M. millerae. The increasing silage diet in a rumen suppressed methanogenesis by reducing population distribution of Methanobacteriales, directly or indirectly, by reducing the diversity of bacterial populations. Generally, the increase silage in the diet changed the bacterial and methanogen community. Grass-legume silage diets of less than $45 \%$ are potential for ruminant diet to reduce methane production by a decrease of $4 \%$ in the relative distribution of methanogens in the rumen.
\end{abstract}

Keywords: 16S rDNA sequence, culture-independent, grass-legumes silage, microbial community

\section{INTRODUCTION}

The rumen a complex microbiome of bacteria and methanogen plays an important role in feed metabolisms. Naturally, methane $\left(\mathrm{CH}_{4}\right)$ is produced during feed fermentation by methanogens in the rumen, which constitutes an energy loss and reduces the productivity of the ruminant. Ruminant is one contributor of enteric $\mathrm{CH}_{4}$ emissions into the environment from the livestock sector (Patra et al. 2012; Ji and Park 2012), and potent greenhouse gas that contributes to global warming and climate change (IPCC 2014; Bodas et al. 2012).

One of the most limiting factors in feeding cattle with forage is nutrient quality and sustainability. Calliandra calothyrsus contains high crude protein (21-30\%) and a total tannin $8-14 \%$. Since crude protein supplies total $\mathrm{N}$ for microbes to synthesize protein, polyphenolics are a useful nutritional strategy to reduces $\mathrm{CH}_{4}$ emissions (Lopez et al. 2010). The increased level of silage diets in a rumen in vitro fermentation system suppressed both methane production and protozoa population (Ridwan et al. 2014). The combination of grasses and legumes (1:1) is an alternative solution for improving the crude protein content of feed for sustainable ruminant production (Ridwan et al. 2015).

Up until recently, information regarding the microbiome community in the rumen of Ongole cattle has been limited. Examination of the microbial community in the rumen, based on cultural methods, has produced limited results that include less than 1-2\% from total microbes and is highly misleading. Molecular analyses, based on cultureindependent methods using the $16 \mathrm{~S}$ rDNA sequence, should be used for additional information of microbial diversity from unculturable rumen microbes. Many useful methods may be used for metagenomic assays based on $16 \mathrm{~S}$ rDNA, such as terminal-restriction fragment length polymorphism (T-RFLP) (Khafipour et al. 2009; Cadillo et al. 2008), 16S rDNA clone library (Danielsson et al. 2012; Fernando et al. 2010), and qPCR (Tajima et al. 2001; Bustin et al. 2009). Moreover, additional data on microbial diversity and clustering will be advantageous. The objective of this study was to investigate the bacteria and methanogen communities in the rumen of Ongole cattle, fed different levels of silage containing C. calothyrsus. 


\section{MATERIALS AND METHODS}

\section{Animals and feedstuffs}

Feeding trials were carried out using three fistulated Ongole cattle (according to consideration of animal welfare), as approved by the Animal Care and Use Committee of Bogor Agricultural University. Silage was produced according to the result of previous research (Ridwan et al. 2014, 2015). Grass-legume silages were made by using a wilted Pennisetum purpureum hybrid (a type of grass) and C. calothyrsus (Fabaceae; red flower) legumes, with the proportion of 50\%:50\% (w/w). The grasses were provided by the plant collection of the Research Center for Biotechnology, Indonesian Institute of Sciences, Cibinong, Bogor, West Java, indonesia. Legumes were collected from PT. Perkebunan Nusantara VIII Gunung Mas Cisarua, Bogor, West Java, Indonesia. Forage was chopped to lengths of approximately $3-5 \mathrm{~cm}$. Readily available carbohydrate $(10 \%)$ and silage inoculants of the Biotechnology Culture Collection of Microorganism, Research Center for Biotechnology, Indonesian Institute of Sciences (Lactobacillus plantarum BTCC570) $\left(2.5 \times 10^{6}\right.$ $\mathrm{CFU} / \mathrm{g}$ silage material) were added as silage additives. The silages were prepared in plastic drum silos (capacity $80 \mathrm{~kg} / \mathrm{drum}$ ). The silages were incubated at room temperature $\left(30^{\circ} \mathrm{C}\right)$ for 30 days. After incubation, the silages were opened for quality analysis before being used for the feeding trial. For the quality evaluation of silages, proximate analysis, fiber fraction, and tannin contents were conducted as described previously (Ridwan et al. 2015).

The experiment was arranged in a cross over design with four treatment diets and three sampling periods as replications. The experimental diets consisted of the following: R0: 50\% Pennisetum purpureum and 50\% concentrate; R1: $20 \%$ P. purpureum, $50 \%$ concentrate, and $30 \%$ grass-legumes silage; R2: $20 \%$ P. purpureum, $35 \%$ concentrate, and $45 \%$ grass-legumes silage; and R3; $20 \%$ $P$. purpureum, $20 \%$ concentrate, and $60 \%$ grass-legumes silage. Each treatment was administered for 17 days, and rumen samples were collected on days 7,12 , and 17 as replication sampling periods. All cattle were given amounts of feed equal to $2 \%$ dry matter of their body weight (245 $\mathrm{kg}$ ). The Nutrient and chemical composition of diets are shown in Table 1.

\section{Sample collection, DNA extraction, and 16S rDNA amplification}

The rumen fluid was obtained from each of the three fistulated cattle 3 hours after morning feeding. Samples of rumen fluid were mixed, homogenized, filtered by using sterilized double cheesecloth, and transferred to a sterilized corning tube. Microbial DNA from the rumen fluid of each treatment was extracted by using a Genomic DNA Mini Kit based on Buffy Coat Protocol (Geneaid) with some modifications (Ridwan et al. 2014, 2015). The DNA from each treatment was pooled from 3 DNA samples collected.
The DNA samples were used for molecular analyses consisted of T-RFLP, 16S rDNA clone library, and qPCR.

The 16S rDNA amplification was performed as described previously by Ridwan et al. $(2014,2015)$. DNA was amplified by using primers 6FAM-27F (5'AGAGTTTGATCCTGGCTCAG3') and 1492R (5'GGTTACCTTGTTACGACTT3') for bacteria and 6FAM-Met86F (5'GCTCAGTAACACGTGG3') and Met1340R 5'CGGTGTGTGCAAGGAG3') for methanogens. Amplification of each PCR reaction was in a total volume of $50 \mu \mathrm{L}$, and consisted of $5 \mu \mathrm{L}$ of dissolved DNA $(<1 \mu \mathrm{g}), 0.5 \mu \mathrm{L}$ of $1.25 \mathrm{U}$ Takara Ex Taq (Takara Shuzo), $5 \mu \mathrm{L}$ of 10x Ex Taq buffer, $4 \mu \mathrm{L}$ of dNTP mixture $\left(2.5 \mathrm{mmolL}^{-1}\right), 10 \mathrm{pmol}$ of each primer and up to $50 \mu \mathrm{L}$ of pure distilled water. The $16 \mathrm{~S}$ rDNA was amplified by using a Biometra Thermocycler TGradient with the following program for bacteria: $95^{\circ} \mathrm{C}$ for $3 \mathrm{~min}$, followed by 30 cycles consisting of $95^{\circ} \mathrm{C}$ for $30 \mathrm{~s}, 50^{\circ} \mathrm{C}$ for $30 \mathrm{~s}$ and $72^{\circ} \mathrm{C}$ for 1.5 min, with a final extension at $72^{\circ} \mathrm{C}$ for $10 \mathrm{~min}$. The program for methanogens was $94^{\circ} \mathrm{C}$ for $5 \mathrm{~min}$, followed by 30 cycles of $94^{\circ} \mathrm{C}$ for $30 \mathrm{~s}, 57^{\circ} \mathrm{C}$ for $30 \mathrm{~s}$, and $68^{\circ} \mathrm{C}$ for 1 min; with a final extension at $68^{\circ} \mathrm{C}$ for $7 \mathrm{~min}$. Amplified DNAs were verified by electrophoresis of $5 \mu \mathrm{L}$ aliquots of PCR product on a $1.5 \%$ agarose gel in $1 \mathrm{x}$ TAE buffer. The PCR products were purified with an Ultra Clean PCR CleanUp Kit (Mo Bio Laboratories, Inc.,). The purified 16S rDNA amplicons were stored at $-20^{\circ} \mathrm{C}$ for further analysis of T-RFLP and 16S rDNA clone library.

\section{Molecular analyses}

T-RFLP analysis was performed as described previously by Ridwan et al. $(2014,2015)$ based on the method of Sakamoto et al. (2006) and Danielsson et al. (2012), with some modification. The conditions of $16 \mathrm{~S}$ rDNA amplification were described above. The purified PCR product $(2 \mu \mathrm{l})$ was digested with four restriction enzymes that consisted of $20 \mathrm{U}$ of $A l u \mathrm{I}, H h a \mathrm{I}, M s p \mathrm{I}$ and $R s a \mathrm{I}$ (TaKaRa Shuzo Japan) in total volume $10 \mu \mathrm{L}$ at $37^{\circ} \mathrm{C}$ for $1 \mathrm{~h}$. The restriction digest product $(2 \mu \mathrm{L})$ was mixed with $8 \mu \mathrm{l}$ of Hi-Di Formamide (Applied Biosystems, Foster City, CA) and $1 \mu \mathrm{L}$ standard Gene Scan ${ }^{\mathrm{TM}} 1200 \mathrm{LIZ}$ (Applied Biosystems, Foster City, CA). Each sample was denatured at $95^{\circ} \mathrm{C}$ for $2 \mathrm{~min}$ and then immediately placed on ice. The length of terminal restriction fragment (T-RF) was determined on an ABI PRISM 3100 Genetic Analyzer (Applied Biosystems). T-RF sizes were estimated by using local method peak scan version 2.0 (Applied Biosystems). T-RFs with area peaks of less than $2 \%$ total area were excluded from the analysis. DNA fragments were resolved to one base pair by manual alignment of the standard peaks from different electropherograms. The T-RF similarity assay was performed using the microbial communities the of $16 \mathrm{~S}$ rDNA clone library. The diversity of the microbial population was determined based on the Shannon index (Magurran. 2004). 
Table 1. Nutrient and chemical composition of diets $(\mathrm{g} / \mathrm{kg}$ dry matter)

\begin{tabular}{lllllllll}
\hline Treatment & OM & CP & EE & NDF & ADF & Lignin & TF & TT \\
\hline R0 & 907.7 & 145.4 & 51.5 & 591.1 & 348.6 & 245.3 & 19.0 & 6.0 \\
R1 & 904.5 & 160.1 & 54.1 & 533.6 & 320.7 & 213.9 & 47.6 & 35.4 \\
R2 & 899.3 & 164.9 & 45.7 & 531.2 & 338.5 & 230.7 & 67.6 & 52.0 \\
R3 & 894.2 & 169.7 & 37.4 & 528.7 & 356.4 & 247.5 & 87.6 & 68.5 \\
\hline
\end{tabular}

Note: OM; Organic matter, CP; crude protein, EE; extract ether, NDF ; Neutral Detergent Fiber, ADF; Acid Detergent Fiber, TF; Total phenol, TT; Total Tannin. R0: 50\% Pennisetum purpureum and 50\% concentrate, R1: $20 \%$ P. purpureum, 50\% concentrate and $30 \%$ silage, R2: $20 \%$ P. purpureum, 35\% concentrate and 45\% silage, and R3: $20 \%$ P. purpureum, $20 \%$ concentrate and 60\% silage

Analysis of the $16 \mathrm{~S}$ rDNA clone library was performed as described previously (Sakamoto et al., 2004) with some modification. The primers used were $27 \mathrm{~F}$ (without FAM) and 1492R for bacteria, and 86Met-F (without FAM) and 1340Met-R for methanogen. The conditions of $16 \mathrm{~S}$ rDNA amplification were described above. Purified PCR product was ligated into plasmid vector $\mathrm{pCR}^{\circledR} 2.1$ and transformed into One Shot ${ }^{\circledR}$ INF $\alpha F^{\prime}$ competent cells, using the original TA cloning kit (Invitrogen, Life Technologies), San Diego, CA). Blue-white selection was used to screen the recombinant colony using $\mathrm{X}$-gal $(40 \mathrm{mg} / \mathrm{mL})$ and ampicillincontaining LB medium. Insertion check for each recombinant colony was conducted by PCR using primer M13F and M13R. Colony insertion DNA was purified using the multiscreen HTS 96 well filtration system (Millipore Corporation, Billerica USA). Plasmid DNA precipitation consisted of $1.25 \mathrm{mM}$ EDTA, 3M sodium acetate, $99.5 \%$ absolute ethanol, and $70 \%$ ethanol using centrifugation. Sequencing was conducted using the $27 \mathrm{~F}$ and 520R primers for bacteria and $86 \mathrm{Met}-\mathrm{F}$ and $520 \mathrm{Met}-\mathrm{R}$ for methanogen, a Big Dye Terminator Cycle Sequencing Kit (Applied Biosystems), and ABI PRISM 3100 Genetic Analyzer (Applied Biosystems). The 16S rDNA sequences were checked using BioEdit base on the sequence of primers and similarity was compared using BLAST search NCBI (Zhang et al. 2000) and Eztaxon database (Kim et al. 2012). The microbial communities of $16 \mathrm{~S}$ rDNA sequence were used for the data of T-RFs in T-RFLP analysis.

Quantitative real-time PCR (qPCR) was performed as described previously (Ridwan et al. 2014) using the LightCycler3 system (Roche Diagnostic) following the manufacturer's instructions and the dsDNA-binding dye SYBR Green I with four pairs of specific primers (Denman and McSweeney 2006; Denman et al. 2007). The total qPCR reaction was in a $20 \mu \mathrm{L}$ final volume consisted of 10 $\mu \mathrm{L}$ of SYBR® premix ExTaq ${ }^{\mathrm{TM}}$ containing TLi RNase $\mathrm{H}$ plus (Takara), $0.4 \mu \mathrm{L}$ of each specific primer (F \& R), 7.2 $\mu \mathrm{L}$ of pure distilled water, and $2 \mu \mathrm{L}$ of extracted DNA sample from each treatment. The total number of bacteria in samples was determined by using Escherichia coli JM 109 cells as a standard. The total number of methanogens (including Methanobacteriales and Methanosarcinales) in samples was determined by using Methanosarcina barkeri JCM 10043T and Methanobrevibacter ruminantium JCM $13430 \mathrm{~T}$ cells as a standard. Data were analyzed by LightCycler analysis software version 5.3 (Roche Diagnostic). The qPCR analysis was used for quantification of the actual specific population of rumen microbes.

\section{RESULTS AND DISCUSSION}

\section{Microbial diversity}

Diversity index of rumen bacteria and methanogen are shown in Table 2. Increasing levels of grass-legume silage diets decreased the diversity index of bacteria. A high diversity index in the rumen indicated that each sample contained a diverse population of microorganisms. The control (R0) showed the highest value of Shannon index and T-RF richness of bacteria compared to the other treatments, while R3 had the lowest diversity index.

In our results, about three species had $>97 \%$ similarity to the $16 \mathrm{~S}$ rDNA database sequences of bacteria. Further, about 25 species of bacterial sequences had $80-96 \%$ similarity to $16 \mathrm{~S}$ rDNA database sequences (Table 3 ). The total $16 \mathrm{~S}$ rDNA sequences of clones analyzed were 114 OTUs (60 OTUs of bacteria and 54 OTUs of methanogen) and consisted of 192 clones in the rumen sample (Table 3). The first and largest cluster contained Bacteriodetes 31 OTUs (51.07\%), followed by Firmicutes $38.3 \%$, Proteobacteria $6.7 \%$, and Actinomycetes $3.3 \%$ of total OTUs (78 clones). Phylum Bacteriodetes had high similarity with 10 rumen bacteria dominated by Prevotella groups. The bacterial abundance showed that the Firmicutes were reduced up to $16 \%$ while Bacteriodetes increased up to $84 \%$ with the increasing total tannins in the silage diets. The proteobacteria abundance was $33 \%$ in the R0 treatment and decreased up to $8 \%$ with R1 treatment. The cluster of methanogens with the order of Methanobacteriales 47 OTUs $(87 \%)$, uncultured archaea $9.3 \%$, and a minority of uncultured methanogens $3.3 \%$ of total OTUs; 114 clones.

Table 2. Diversity index of rumen bacteria and methanogen

\begin{tabular}{lcccc} 
Treatments & \multicolumn{2}{c}{ Shanon index (H') } & \multicolumn{2}{c}{ Richness (S) } \\
Bacteria & Methanogen & Bacteria & Methanogen \\
R0 & $3.46 \pm 0.25$ & $2.32 \pm 0.05$ & 49 & 17 \\
R1 & $3.41 \pm 0.24$ & $2.31 \pm 0.15$ & 38 & 17 \\
R2 & $3.03 \pm 0.08$ & $2.42 \pm 0.49$ & 24 & 20 \\
R3 & $2.07 \pm 0.22$ & $1.21 \pm 0.25$ & 11 & 5 \\
\hline
\end{tabular}

Note: R0: 50\% Pennisetum purpureum and 50\% concentrate, R1: $20 \%$ P. purpureum, $50 \%$ concentrate and $30 \%$ silage, R2: $20 \% P$. purpureum, $35 \%$ concentrate and $45 \%$ silage, and R3: $20 \% P$. purpureum, $20 \%$ concentrate and $60 \%$ silage 
Table 3. Similarity values of bacteria and methanogen based on 16S rDNA sequences of clones from the rumen sample of Ongole cattle

\begin{tabular}{|c|c|c|c|c|c|c|}
\hline \multirow{2}{*}{ Nearest valid relative } & \multirow{2}{*}{ Accession no. } & \multirow{2}{*}{ Similarity $(\%)$} & \multicolumn{4}{|c|}{ No. of OTU (Clone) of Treatment } \\
\hline & & & R0 & R1 & $\mathbf{R 2}$ & R3 \\
\hline Barnesiella viscericola & AB267809 & 83 & & & & $1(1)$ \\
\hline Butyricimonas virosa & AB443949 & 83 & & & $1(1)$ & \\
\hline Butyrivibrio hungatei & AJ428553 & $92 / 94$ & & $1(1)$ & $1(1)$ & \\
\hline Butyrivibrio proteoclasticus & CP001810 & 95 & & & & $1(1)$ \\
\hline Catabacter hongkongensis & AY574991 & 86 & $1(2)$ & & & \\
\hline Clostridium aldenense & DQ279736 & 93 & & $1(1)$ & & \\
\hline Clostridium clostridioforme & M59089 & 90 & & $1(1)$ & & \\
\hline Clostridium thermocellum & СР000568 & 84 & & $1(1)$ & & \\
\hline Coprococcus eutactus & ABEY02000028 & $93 / 94$ & & & $1(1)$ & $1(1)$ \\
\hline Desulfococcus multivorans & AF418173 & 80 & $1(1)$ & & & \\
\hline Eubacterium ruminantium & $\mathrm{AB} 008552$ & 93 & & $1(1)$ & & \\
\hline Eubacterium siraeum & ABCA03000019 & $90 / 93$ & & $1(1)$ & & $1(1)$ \\
\hline Paludibacter propionicigenes & CP002345 & 84 & & & $1(1)$ & \\
\hline Prevotella albensis & AJ011683 & 96 & & & & $1(1)$ \\
\hline Prevotella brevis & AJ011682 & $90-92$ & $2(2)$ & & $6(6)$ & $5(5)$ \\
\hline Prevotella bryantii & ADWO01000056 & 88 & $2(3)$ & & & \\
\hline Prevotella dentalis & AFPW01000057 & 90 & & & & $1(1)$ \\
\hline Prevotella massiliensis & AF487886 & 91 & & $1(1)$ & & \\
\hline Prevotella ruminicola & CP002006 & $90-98$ & & $3(4)$ & $1(1)$ & $7(7)$ \\
\hline Prevotella veroralis & L16473 & 90 & $1(1)$ & & & \\
\hline Quinella ovalis & M62701 & 92 & $2(2)$ & & & \\
\hline Roseburia intestinalis & AJ312385 & 86 & & & $1(1)$ & \\
\hline Ruminobacter amylophilus & Y15992 & 92 & & $1(1)$ & & \\
\hline Selenomonas bovis & EF139191 & 88 & & & $1(1)$ & \\
\hline Streptomyces harbinensis & JQ750974 & $82 / 84$ & & & $2(2)$ & \\
\hline Succiniclasticum ruminis & X81137 & $91-100$ & $6(11)$ & $1(1)$ & $1(1)$ & \\
\hline Succinivibrio dextrinosolvens & Y17600 & $86-97$ & $2(9)$ & & & \\
\hline Methanobrevibacter ruminantium & AY196666 & $95-97$ & $8(12)$ & $7(10)$ & $5(9)$ & \\
\hline Methanobrevibacter smithii & СР000678 & $97-99$ & $4(11)$ & $8(11)$ & $4(9)$ & $3(4)$ \\
\hline Methanobrevibacter thaueri & U55236 & $98-99$ & $4(5)$ & $7(10)$ & $3(8)$ & $4(11)$ \\
\hline Methanobrevibacter millerae & AY196673 & 99 & $1(2)$ & $1(1)$ & & $1(1)$ \\
\hline Methanosphaera stadtmanae & CP000102 & 96 & & & $2(2)$ & \\
\hline Uncultured methanogen clone & KC454249 & 91 & & $1(1)$ & & \\
\hline Uncultured methanogen clone & EU413649 & 99 & & & $1(1)$ & \\
\hline Uncultured archaeon clone & JF807295 & 99 & & & $1(1)$ & \\
\hline Uncultured archaeon clone & GU329824 & 99 & & & $1(1)$ & \\
\hline Uncultured archaeon clone & GU329771 & 99 & & & $1(1)$ & \\
\hline Uncultured archaeon clone & AB535295 & 99 & & & $1(1)$ & \\
\hline Uncultured archaeon clone & JQ845958 & $99 / 100$ & & $1(1)$ & $1(1)$ & \\
\hline
\end{tabular}

\section{Bacteria and methanogen community}

DNA polymorphisms from each treatment illustrated the diversity of the bacteria and methanogen population consisting of three groups based on the length of T-RFs in R0 treatment (Figure 1). The treatment of silage diets indicated the tendency of group 2, 3 and all population of bacteria to be decreased. In the $\mathrm{R} 2$ treatment, several bacteria populations did not survive including, Selenomonas bovis, Butyrivibrio proteoclasticus, Clostridium clostridioforme, Desulfococcus multivorans, Roseburia intestinalis, Quinella ovalis, and the visual evidence of Butyrivibrio hungatei. The bacterial population in the rumen of R3 treatment was dominated by Prevotella brevis, $P$. ruminicola, $P$. bryantii, $P$. albensis, $P$. massiliensis, Butyrivibrio hungatei, Coprococcus eutactus, Eubacterium siraeum, Ruminobacter amylophilus, and
Selenomonas bovis. Three groups of methanogen populations were dominant with R0 treatment, and consisted of Methanobrevibacter ruminantium, M. smithii, M. thaueri, M. Millerae, Methanosphaera stadtmanae, and uncultured clones of an archaeon and a methanogen. The methanogen population after R2 treatment decreased in the first and second groups (Figure 1.B). Meanwhile, in the R3 treatment, the first and third groups of methanogens were significantly decreased.

The inclusion of feed affected the distribution and composition of bacteria and methanogen. The increasing level of silage decreased methanogen distribution (Figure 2). High level of silage, up to $60 \%$, decreased the distribution of about $50 \%$ of Firmicutes and methanogens, which were dominated by an abundance of Bacteriodetes. 

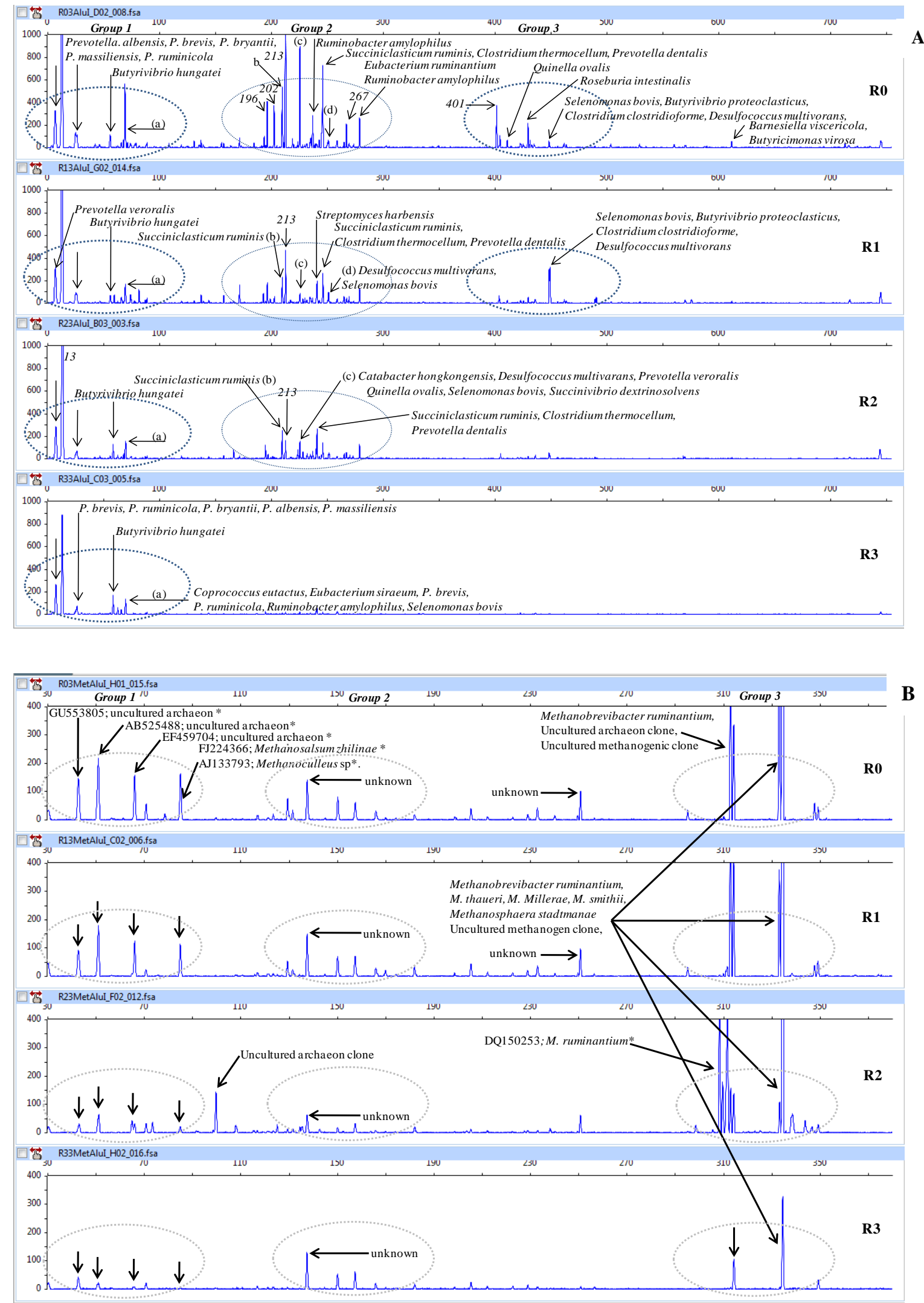

Figure 1. T-RFLP Profile of bacteria (A) and methanogen (B) from rumen fluid digested with restriction enzyme AluI. R0: 50\% Pennisetum purpureum and 50\% concentrate, R1: 20\% P. purpureum, 50\% concentrate and 30\% silage, R2: 20\% P. purpureum, $35 \%$ concentrate and 45\% silage, and R3: $20 \%$ P. purpureum, $20 \%$ concentrate and $60 \%$ silage 

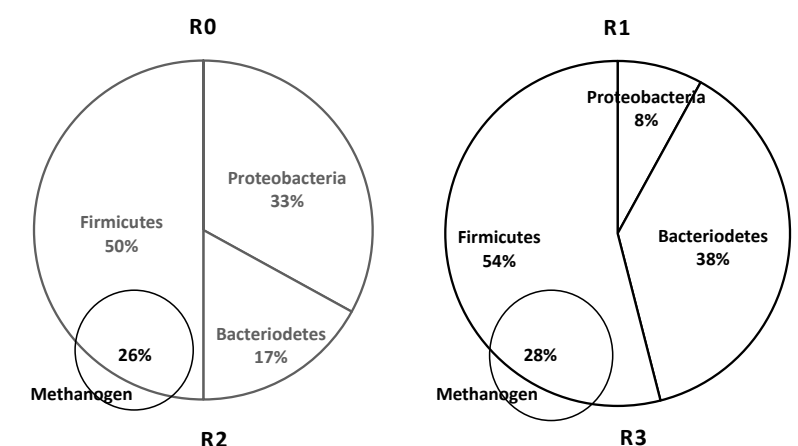

R2
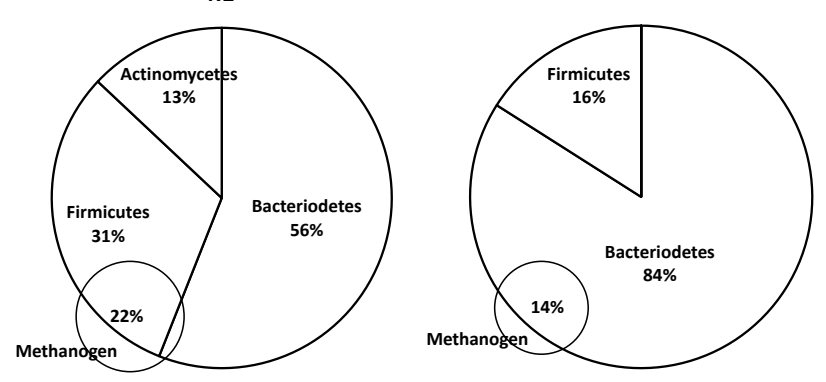

Figure 2. The distribution profile of rumen bacteria and methanogens based on 16S rDNA clone library. R0: 50\% Pennisetum purpureum and 50\% concentrate, R1: $20 \% \quad P$. purpureum, $50 \%$ concentrate and $30 \%$ silage, R2: $20 \% P$. purpureum, $35 \%$ concentrate and $45 \%$ silage, and R3: $20 \% P$. purpureum, $20 \%$ concentrate and $60 \%$ silage

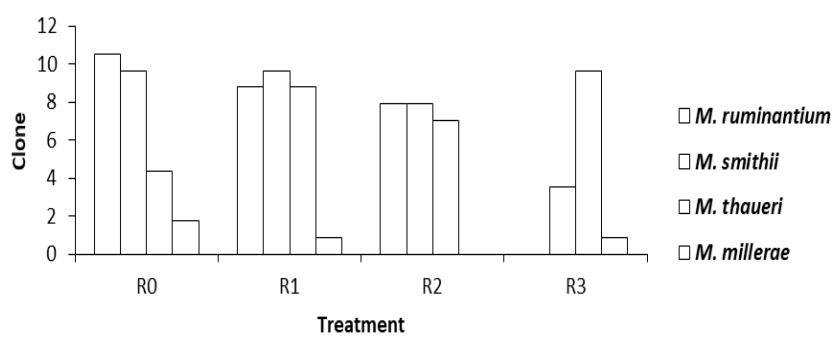

Figure 3. The distribution of rumen methanogen based on $16 \mathrm{~S}$ rDNA clone library. R0: 50\% Pennisetum purpureum and 50\% concentrate, R1: $20 \%$ P. purpureum, 50\% concentrate and $30 \%$ silage, R2: $20 \%$ P. purpureum, $35 \%$ concentrate and $45 \%$ silage, and R3: $20 \%$ P purpureum, $20 \%$ concentrate and $60 \%$ silage.
Figure 3. showed the distribution pattern of methanogens in R0 treatment tended to be dominated by $M$. ruminantium and $M$. smithii. The inclusion of silage diets changed the pattern of methanogen abundance, and differences in the pattern of $M$. thaueri, which was increased with increasing levels of silage in the diets.

The qPCR results of bacteria contained approximately $2.9-4.6 \times 10^{11}$ DNA copy numbers. The Methanobacteriales and Methanosarcinales populations were decreased in DNA copy number with increasing level of silage diets, respectively (Table 4). The decreasing pattern of total methanogens by qPCR was in line with distribution abundance based on the $16 \mathrm{~S}$ rDNA clone library.

\section{Discussion}

Feeding Silage to cattle generally decreased microbial diversity. The increasing levels of grass-legume silages in the diet decreased the microbial diversity index of bacteria (Table 2). T-RFLP analysis followed by partial $16 \mathrm{~S}$ rDNA sequences from clone library gave accurate information for T-RF identity of bacteria and methanogens. These results are in line with Danielsson et al. (2012) that described how a clone library might be used as a reference of rumen microbial similarity for T-RFLP analysis. The Prevotella group (Bacteriodetes), especially $P$. ruminocola, was identified as rumen bacteria with high resistance to tannin treatment (Jones et al. 1994). The resistance mechanisms of $P$. ruminocola might be due to its ability to degrade phenolic compounds and high proteolytic activities in the rumen. Li et al. (2013) reported that high tannin content in the diet was indicated by the domination of Bacteriodetes followed by Proteobacteria and Firmicutes.

The abundance of Firmicutes and Bacteriodetes effectively reduced the relative distribution of methanogen in the rumen, based on molecular methods in this study. The distribution abundance of Bacteriodetes was dominated by $P$. brevis and $P$. ruminocola as propionate producer. The predominance of Prevotella played a role in utilizing fibrous substrates or tannin. These patterns of distribution abundance were similar to those of Mitsumori et al. (2012) who reported that treatments of high concentration of bromochloromethane (BCM) increased the abundance of Prevotella and reduced enteric $\mathrm{CH}_{4}$ in the rumen. Recently, the use of BCM was banned due to environmental safety concerns, so tannin could be used as an alternative solution for reducing enteric $\mathrm{CH}_{4}$ emissions in the rumen (Bodas et al. 2012; Tiemann et al. 2008).

Table 4. Quantification of rumen microbes by qPCR (Copy number)

\begin{tabular}{|c|c|c|c|c|}
\hline \multirow{2}{*}{ Microbial target } & \multicolumn{4}{|c|}{ Treatments } \\
\hline & R0 & R1 & $\mathbf{R 2}$ & R3 \\
\hline Total bacteria & $2.9 \times 10^{11}$ & $4.13 \times 10^{11}$ & $4.64 \times 10^{11}$ & $3.46 \times 10^{11}$ \\
\hline $\begin{array}{l}\text { Total methanogens of } \\
\text { Methanobacteriales } \\
\text { Methanosarcinales }\end{array}$ & $\begin{array}{l}2.7 \times 10^{8} \\
2.1 \times 10^{6}\end{array}$ & $\begin{array}{l}3.5 \times 10^{8} \\
1.5 \times 10^{6}\end{array}$ & $\begin{array}{l}9.7 \times 10^{7} \\
1.5 \times 10^{6}\end{array}$ & $\begin{array}{l}8.6 \times 10^{5} \\
8.3 \times 10^{5}\end{array}$ \\
\hline
\end{tabular}

Note: R0: 50\% Pennisetum purpureum and 50\% concentrate, R1: 20\% P. purpureum, 50\% concentrate and 30\% silage, R2: $20 \%$ P. purpureum, $35 \%$ concentrate and 45\% silage, and R3: $20 \%$ P. purpureum, $20 \%$ concentrate and 60\% silage 
The dominance pattern of the rumen microbiome was more influenced by diet. This study observed that the Prevotella population proliferated up to $80 \%$ on forages diets. This finding suggested that grass-legume silage diets with high protein content significantly affected the population of Prevotella. However, the population of Prevotella was lower than other propionate producers in the R3 treatment (unpublish data). It suggested that the activity of propionate producing bacteria was inhibited by tannin content and the other rumen microbes were able to utilize tannin and lactic acid to produce acetic acid.

High tannin content in the silage diets might directly affect bacteria, protozoa, and methanogen, and indirectly affect methanogen activity (Patra et al. 2012; Kamra et al. 2012). The distribution pattern was dominated by Succinilacticum ruminis abundance (Table 2), known as an acid utilizer and acetic acid producing bacteria. Mitsumori et al. (2014) reported that the use of $\mathrm{CH}_{4}$ inhibitors significantly changed the population composition of acetogen bacteria. The homoacetogen groups utilized $\mathrm{H}_{2}$ and $\mathrm{CO}_{2}$ to produce acetic acid, while the methanogen group activities were inhibited. Methanobrevibacter ruminantium, $M$. smithii, $M$. thaueri, $M$. millerae, and Methanosphaera stadtmanae are culturable $\mathrm{CH} 4$-producing methanogens and were successfully cloned from in vivo rumen fermentation. $M$. ruminantium was not found in R3 treatment, although in the T-RFLP analysis there was a similarity with T-RFs of four other methanogens. These results indicated that $M$. ruminantium could not survive with the increase of tannin-containing silages in the diet. The Methanobrevibacter was dominant in the rumen, but its activities were inhibited by the decrease of the protozoa population and tannin (Zhou et al. 2011). Considering the volatile fatty acid (VFA) production (unpublish data) and the diversity of bacteria, the diet with $45 \%$ grass-legume silage (R2) improved the efficiency in reducing the relative distribution of methanogen by $4 \%$. This finding suggests that the silage diets containing tannin were sufficient in nutrition for the rumen fermentation process and were able to reduce the relative distribution of methanogens.

High concentration of total tannin in the diets inhibits fed digestibility, absorption, and $\mathrm{CH}_{4}$ production in the rumen. The beneficial effect of tannin in rumen fermentation, to reduce $\mathrm{CH}_{4}$ emission and gas production, has been reported by several authors (Bodas et al. 2012; Lopez et al. 2010; Castro-Montoya et al. 2011; Jayanegara et al. 2015). In these results, total tannin also indicated the beneficial effect of reducing the methanogen diversity index. Silages can be used as an alternative sustainable feed supplement to improve ruminant performance (GómezVázquez et al. 2011; Wanapat et al. 2014). The silage with a 50\%:50\% grass-legume combination had adequate nutritional value, based on the standard requirements of ruminant feed (Ridwan et al. 2015). This formulation has been studied in in-vivo rumen fermentation to establish a suitable level of the diets. This mechanism potentially inhibited $\mathrm{CH}_{4}$ production to decrease energy loss. The total tannin contained in silages was less than $52 \mathrm{~g} / \mathrm{kg}(5.2 \%)$ of dry matter basis and contributed to reducing the relative distribution of methanogens in the rumen.

Furthermore, the abundance of methanogens in this study was in line with the predominance of Methanobrevibacter (methanobacteriales) as the hydrogenotrophic methanogen (Singh et al. 2012; Franzolin et al. 2012). The type of this methanogen was able to utilize $\mathrm{H}_{2}$ and $\mathrm{CO}_{2}$ for enteric $\mathrm{CH}_{4}$ production. The M. smithii, M. gottschalkii, M. millerae, and M. thaurei were also found with different distribution patterns (King et al. 2011). The abundance pattern of $M$. thaueri was pervasive in silage diets with high tannin content, because of high GC DNA content and good growth in a high protein diet compared with $M$. rumiantium dan $M$. smithii (Miller et al. 2002). The increase of methanogens was similar to that reported by Radovan et al. (Radovan et al. 2013) who reported that feed with high tannin content caused predominance of $M$. thauri dan M. millerae. The abundance of Methanobacteriales and Methanosarcinales methanogens were identified with the qPCR analysis in the rumen (Table 4). The predominance of Methanobacteriales was correlated with energy conservation produced from $\mathrm{H}_{2}$ and $\mathrm{CO}_{2}$ substrate. The Methanosarcinales groups were not found in the results with T-RFLP and 16S rDNA clone library analysis. This finding suggested that Methanosarcinales was a minority group in the rumen. These methanogens required acetate as an electron donor in their metabolisms (Ferry. 2015). The acetate, as the main VFA in the rumen, is used as the main energy source for ruminants (Bergman. 1990). This acid is available in the rumen approximately $50-70 \%$ of total VFA, $75 \%$ was utilized as energy sources and absorbed in the rumen epithelial cells, and unfortunately, Methanosarcinales cannot use more acetate substrate in the rumen.

In summary, these results provided additional information to a previous study based on an in vitro fermentation system, with correlation to the complex dynamic diversity population based on molecular studies. Generally, the community of bacteria and methanogens were changed with the increasing concentration of grasslegume silages in the diet. Grass-legume silage diets, with less than $45 \%$ or contain $5.2 \%$ total tannin, improved feed efficiency and potential diet for ruminant to reduce methane production by decreasing $4 \%$ of the relative distribution of methanogens in the rumen.

\section{ACKNOWLEDGEMENTS}

This research was supported by DIPA of the Research Center for Biotechnology-Indonesian Institute of Sciences, Japan Collection of Microorganisms-RIKEN BioResource Center for supporting metagenomic analysis in Japan, and Ministry of Research and Technology of Indonesia Government for providing a scholarship. In addition, the authors would like to thank Center of Excellence of Biotechnology Animal of Beef Cattle and Dairy Cattle (PUI Kemenristek Dikti 2019) for supporting this publication. 


\section{REFERENCES}

Bergman EN. 1990. Energy contributions of volatile fatty acids from the gastrointestinal tract in various species. Physiol Rev 70: 567-590.

Bodas R, Prieto N, Garcia-Gonzalez R, Andres S, Giraldez FJ, Lopez S. 2012. Manipulation of rumen fermentation and methane production with plant secondary metabolites. Anim Feed Sci Technol 176: 78-93.

Bustin SA, Benes V, Garson JA, Hellemans J, Huggett J, Kubista M, Mueller R, Nolan T, Pfaffi MW, Shipley GL, Vandesompele J, Wittwer CT. 2009. The MIQE guidelines: minimum information for publication of quantitative real-time PCR experiments. Clin Chem 55 (4): 611-622.

Cadillo QH, Yashiro E, Yavitt JB. Zinder SH. 2008. Characterization of the archaeal community in a minerotrophic fen and terminal restriction fragment length polymorphism-directed isolation of a novel hydrogenotrophic methanogen. Appl Environ Microbiol 74 (7): 2059-2068.

Castro-Montoya JM, Makkar HPS, Becker K. 2011. Chemical composition of rumen microbial fraction and fermentation parameters as affected by tannin and saponins using an in vitro rumen fermentation. Can J Anim Sci 91: 433-448.

Danielsson R, Schnurer A, Arthurson V, Bertilsson J. 2012. Methanogenic population and $\mathrm{CH}_{4}$ production in Swedish dairy cows fed different levels of forage. Appl Environ Microbiol 78 (17): 6172-6179.

Denman SE, McSweeney CS. 2006. Development of a real-time PCR assay for monitoring anaerobic fungal and cellulolytic bacterial populations within the rumen. FEMS Microbiol Ecol 58: 572-582.

Denman SE, Tomkins NW, McSweeney CS. 2007. Quantitation and diversity analysis of ruminal methanogenic populations in response to the antimethanogenic compound bromochloromethane. FEMS Microbiol Ecol 62: 313-322.

Fernando SC, Purvis II HT, Najar FZ, Sukharnikov LO, Krehbiel CR, Nagaraja TG, Roe BA, DeSilva U. 2010. Rumen microbial population dynamics during adaptation to a high-grain diet. Appl Environ Microbiol 76 (22): 7482-7490.

Ferry JG. 2015. Acetate Metabolism in Anaerobes from the Domain Archaea. Life 5: 1454-1471

Franzolin R, St-Pierre B, Northwood K, Wright A-DG. 2012. Analysis of Rumen Methanogen Diversity in Water Buffaloes (Bubalus bubalis) Under Three Different Diets. Microb Ecol 64: 131-139.

Gómez-Vázquez A, Pinos-Rodríguez JM, García-López JC, de la CruzLázaro E, Luna-Palomera C, Sánchez-Hernández R. 2011. Nutritional value of sugarcane silage enriched with corn grain, urea, and minerals as feed supplement on growth performance of beef steers grazing stargrass. Trop Anim Health Prod 43 (1): 215-220.

Intergovernmental Panel on Climate Change 2014. Climate Change 2014 Synthesis Report 2015.

Jayanegara A, Goel G, Makkar HPS, Becker K. 2015. Divergence between purified hydrolysable and condensed tannin effects on methane emission, rumen fermentation andmicrobial population in vitro. Anim Feed Sci Technol 209: 60-68

Ji ES, Park K. 2012. Methane and nitrous oxide emissions from livestock agriculture in 16 local administrative districts of Korea. Asian-Aust. J Anim Sci 25: 1768-1774.

Jones GA, McAllister TA, Muir AD, Cheng KJ. 1994. Effects of sainfoin (Onobrychis viciifolia Scop.) condensed tannins growth and proteolysis by four strains of ruminal bacteria. Appl Environ Microbiol 60 (4): 1374-1378.

Kamra, DN, Pawar M, Singh B. 2012. Effect of plant secondary metabolites on rumen methanogens and methane emissions by ruminants. In: AK Patra (Ed). Dietary Phytochemicals and Microbes. Springer Science+Business Media Dordrecht 351-370.

Khafipour E, Li S, Plaizier JC, Krause DO. 2009. Rumen microbiome composition of subacute ruminal acidosis determined using two nutritional models. Appl Environ Microbiol 75 (22): 7115-7124.

Kim OS, Cho YJ, Lee K, Yoon SH, Kim M, Na H, Park SC, Jeon YS, Lee $\mathrm{JH}$, Yi H, Won S, Chun J. 2012. Introducing EzTaxon-e: a prokaryotic $16 \mathrm{~S}$ rRNA gene sequence database with phylotypes that represent uncultured species. J Syst Evol Microbiol 62: 716-721.
King EE, Smith RP, St-Pierre B. Wright A-DG. 2011. Differences in the rumen methanogen populations of lactating jersey and holstein dairy cows under the same diet regimen. Appl Environ Microbiol 77 (16): 5682-5687.

Li ZP, Liu HL, Li GY, Bao K, Wang KY, Xu C, Yang YF, Yang FH, Wright A-DG. 2013. Molecular diversity of rumen bacterial communities from tannin-rich and fiber-rich forage fed domestic Sika deer (Cervus nippon) in China. BMC Microbiol 13 (151): 1-12

Lopez S, Makkar HPS, Solivia CR. Screening plants and plant products for methane inhibitors. In: Vercoe PE, Makkar HPS, Schlink AC (Eds). 2010. In Vitro Screening of Plant Resources for ExtraNutritional Attributes in Ruminants: Nuclear and Related Methodologies. Springer, Dordrecht.

Magurran AE. 2004. Measuring Biological Diversity. Malden, MA: Blackwell Publishing.

Miller TL, Lin C. 2002. Descriptionof Methanobrevibacter gottschalkii sp. nov., Methanobrevibacter thaueri sp. nov., Methanobrevibacter woesei sp. nov. and Methanobrevibacter wolinii sp. nov Int J Syst Evol Microbiol 52 (Pt3): 819-822.

Mitsumori M, Shinkai T, Takenaka A, Enishi O, Higuchi K, Kobayashi Y, Nonaka I, Asanuma N, Denman SE, McSweeney CS. 2012. Responses in digestion, rumen fermentation and microbial populations to inhibition of methane formation by a halogenated methane analogue. Br J Nutr 108 (3): 482-491.

Mitsumori M, Matsui H, Tajima K, Shinkai T, Takenaka A, Denman SE, McSweeney CS. 2014. Effect of bromochloromethane and fumarate on phylogenetic diversity of the formyltetrahydrofolate synthetase gene in bovine rumen. Anim Sci J 85: 25-31.

Patra AK, Min B, Saxena J. 2012. Dietary tannin on microbial ecology of the gastrointestinal tract in ruminants. In: Patra AK (ed). Dietary Phytochemicals and Microbes. Springer Science+Business Media Dordrecht 37-262.Radovan GA,Sevilla CC, Capitan SS, Vega RSA, Alcantara AJ, Yebron MGN. 2013. Molecular diversity of rumen methanogen in cattle in response to dietary tannin. Philipp J Vet Anim Sci 39 (1): 121-130.

Ridwan R, Rusmana I, Widyastuti Y, Wiryawan KG, Prasetya B, Sakamoto M, Ohkuma M. 2014. Methane Mitigation and Microbial Diversity of Silage Diets Containing Calliandra calothyrsus in a Rumen In Vitro Fermentation System. Med Pet 37 (2): 121-128.

Ridwan R, Rusmana I, Widyastuti Y, Wiryawan KG, Prasetya B, Sakamoto M, Ohkuma M. 2015. Fermentation characteristics and microbial diversity of tropical grass-legumes silages. Asian-Aust J Anim Sci 28: 511-518.

Sakamoto M, Rocas IN, Siqueira Jr JF. Benno Y. 2006. Molecular analysis of bacteria in asymptomatic and symptomatic endodontic infection. Oral Microbiol Immunol 21: 112-122.

Singh KM, Tripathi AK, Pandya PR, Parnerkar S, Rank DN, Kothari RK, Joshi CG. 2012. Methanogen diversity in the rumen of Indian Surti buffalo (Bubalus bubalis), assessed by $16 \mathrm{~S}$ rDNA analysis. Res Vet Sci 92 (3): 451-455.

Tajima K, Aminov RI, Nagamine T, Matsui H, Nakamura M, Benno Y. 2001. Diet-dependent shifts in the bacterial population of the rumen revealed with real-time PCR. Appl Environ Microbiol 67 (6): 27662774

Tiemann TT, Lascano CE, Wettstein HR, Mayer AC, Kreuzer M, Hess HD. 2008. Effect of the tropical tannin-rich shrub legumes Calliandra calothyrsus and Flemingia macrophylla on methane emission and nitrogen and energy balance in growing lambs. Animal 2: 790-799.

Wanapat M, Kang S, Khejornsart P, Pilajun R, Wanapat S. 2014. Performance of tropical dairy cows fed whole crop rice silage with varying levels of concentrate. Tropical Animal Health and Production 46: $185-189$.

Zhang Z, Schwartz S, Wagner L. Miller W. 2000. A greedy algorithm for aligning DNA sequences. J Comput Biol 7 (1-2): 203-214.

Zhou YY, Mao HL, Jianga F, Wang JK, Liu JX, McSweeney CS. 2011. Inhibition of rumen methanogenesis by tea saponins with reference to fermentation pattern and microbial communities in Hu sheep. Anim Feed Sci Technol 166-67: 93-100. 